International Journal of Operations \& Production Management, 1998, Vol. 18, No. 5, pp424-451

\title{
Operations Management Teaching on European MBA Programmes
}

\author{
Keith Goffin \\ Cranfield School of Management, England, UK
}

\begin{abstract}
A comprehensive review of the literature established that several investigations have been made of operations management teaching in the United States, whereas almost nothing has been published on European teaching. Therefore, an exploratory investigation was made of operations management teaching on the MBA courses of ten leading European business schools. The results show that course content is similar across schools but there are large variations on three dimensions; the time allocated by schools to the subject; the balance between operations strategy and tools and techniques in teaching; and the level of emphasis given to service operations. The results also indicate the emerging importance of integrating operations management with other subjects in the MBA curriculum and the key challenge facing faculty-the need to raise the perceived the importance of operations management. The comparison of courses will be of interest to all OM faculty who teach core courses and particularly those who are looking for ideas on how to re-design courses.
\end{abstract}

\section{KEYWORDS}

Operations management teaching, pedagogy, MBA programmes

\section{AUTOBIOGRAPHICAL NOTE}

Keith Goffin joined Cranfield School of Management as a Lecturer in Operations Management in 1995, after a successful career in the medical electronics industry with the Hewlett-Packard Company. His research interests are innovation, new product development and supplier management. email address: k.goffin@Cranfield.ac.uk INTRODUCTION 
How is operations management taught in European business schools? What are the trends and issues in teaching this subject? These were the sort of the questions which prompted an exploratory investigation of operations management (OM) courses provided within the MBA programmes of ten leading European business schools.

Although OM teaching has been the subject of numerous studies in the US, little has been published on European MBA teaching. This is a significant gap, since important insights can potentially be gained by comparing the teaching strategies of different business schools. As a new member of the teaching faculty at a UK business school, the author attended the 1996 International Teachers Programme (ITP), organised by the International Schools of Business Management at London Business School. A survey of OM teaching was made as a project for ITP and the results presented here - a detailed analysis of European core MBA teaching at ten schoolswill be useful to all faculty who teach OM, particularly those who are designing or redesigning courses and subsequently looking for ideas.

The goals of the research project were defined in preliminary discussions with six faculty at three different schools, who were asked which aspects of OM teaching at other schools would they most interested in learning about. They expressed strong interest in the research and the following research questions:

1) How is OM taught on full-time MBA courses at ten European business schools?

What approaches are there to:

i) course content?

ii) teaching methods?

iii) assessment methods?

iv) integration of $\mathrm{OM}$ with other subjects? 
2) What are the views of $\mathrm{OM}$ faculty on the key challenges they will face in the future in teaching the subject?

\section{TEACHING OPERATIONS MANAGEMENT}

Although the focus of this paper is MBA teaching, the substantial body of literature on OM teaching-including undergraduate, postgraduate and executive teaching-was reviewed, in order to obtain a comprehensive picture. Many of the papers on teaching originate from the US where the subject is normally referred to as production and operations management (POM). In this paper both terms-OM and POM-will be used, with the latter being used to indicate US courses. The relevant topics in the literature will be presented in categories which closely match the focus of the first research question.

- Course content

- Teaching methods

- Assessments

- Integration with other subjects

- Perceptions of OM

\section{$\underline{\text { Course Content }}$}

The choice of course content is generally acknowledged in the literature as key to achieving the aims of OM teaching. Apparently, however, there is little consensus on the content of operations management courses in the US.

A 1989 survey of 431 teachers at US business schools showed a wide diversity in the content of their POM undergraduate courses (Raizadeh and Ettkin, 1989). This wide variation in content between schools was viewed negatively by the researchers 
who stated "although there are advantages to diversity, too much of it in an academic discipline can lead to a lack of focus and potential for confusion" (ibid). Investigating operations management teaching on MBA courses, Bahl surveyed 31 US business schools and found: "there seems to be considerable disagreement as to what should be taught in a POM option" (Bahl, 1989).

Several descriptions of US core MBA courses were presented at a US conference [see for instance (Donohue, 1996), (Bowen, 1996) and (Chand, 1996)] and these also showed some differences in content. However, since information on European OM courses has not been published, no evidence exists that the variations in course content that have been identified in the US are found in Europe. In a study of European MBA core course teaching, course content obviously needs to be thoroughly investigated as the only published information on European teaching is a description of an undergraduate course and an MBA elective (Armistead et al, 1986).

The differences in course content in the US appear to be the result of three main factors:

- In the past OM courses have normally presented tools and techniques. However, there is also a need for a the strategic aspects of $\mathrm{OM}$ to be taught and so there is a tension between covering techniques in detail and focusing on operations strategy.

- Operations management evolved from studies of the manufacturing sector but, due to the shift in many economies towards service, there is a need to cover service operations in $\mathrm{OM}$ courses. Faculty must strike the right balance between service and manufacturing operations.

- There are new areas of $\mathrm{OM}$, such as international manufacturing operations, which potentially need to be covered in core courses. These newer topics compete for time with the more traditional areas of OM. 


\section{Tools or Strategy?}

Traditionally, OM courses have been based around a number of tools and techniques (Adler, 1989) (Hill, 1996), and this means that OM has been taught differently to the way it is practised in successful organisations (Davies, 1996). Consequently, there is a need for the strategic importance of the subject to be underlined by the inclusion of operations strategy in teaching courses (Adler, 1989)(Bahl, 1989).

Bergman and Flores (1991) argue strongly that strategic aspects of OM need to be more highly emphasised, rather than techniques. It has also been argued that teaching which is based on too many, often unrelated, tools and techniques is an ineffective way to convey "the excitement, magnitude and complexity" of operations management (Hill, 1987). Consequently, appropriate teaching materials are required which cover strategic issues effectively. It is important that students understand that operations strategy should be the driver which leads to the adoption of appropriate tools and techniques and not vice versa-operations strategy must therefore be at the centre of OM teaching (Wood and Britney, 1988). Since teaching more operations strategy will take time away from the tools and techniques, the question arises: what is right balance between strategy and techniques? In answer to this, one author has recommended that $40 \%$ of postgraduate sessions should be allocated to strategy (Hill, 1996).

Support for the argument that strategic issues should be covered in OM courses also comes from practitioners. Since practitioners have day-to-day experience of the issues in OM, their views on teaching "should be given some merit and consideration in structuring the introductory POM course" (Berry, 1979). Survey results (ibid) showed that 181 operations managers in US companies thought POM 
concepts and strategy were more important than too much detail on techniques. Similarly Levenburg (1996) found that practising managers thought the emphasis of POM courses should be concepts, as opposed to tools and techniques.

From the literature it is clear that the right balance between strategic issues and tools and techniques needs to be achieved.

\section{Service or Manufacturing?}

It is important to cover service operations in OM teaching (Wood and Britney, 1988). However, undergraduate POM courses in the US were found to place too little emphasis on service operations (Raizadeh and Ettkin, 1989). In contrast, Bahl's 1989 study of 31 US MBA courses showed that "both manufacturing and service sector applications are now covered in most POM courses", although the level of detail on service issues varied. For instance, most schools taught manufacturing planning and control but did not cover teach how planning and control is managed in the service sector. Rather than separating manufacturing and service, it has been argued that a better approach is to fully integrate service and manufacturing topics throughout OM courses (Bregman and Flores, 1991).

There is also pressure from students for service to be comprehensively addressed in core programmes (Armistead et al, 1986). Appropriate materials (e.g. service case studies) should be used to show "that all operations management techniques and approaches can be applied in the service environment" (ibid). It has also been claimed that covering service operations management gives students a better understanding of OM (Killeya and Armistead, 1983).

From the extant literature, it is clear that the right mix of manufacturing and service operation-based material needs to be used. 


\section{Which OM Topics?}

There is much scope to include new topics within OM courses, as the subject is broad (Berry, 1979). It is also a rapidly changing subject [(Bergman and Flores, 1991)(Hill, 1996)], and so there is a need to generate relevant, up-to-date material for teaching which reflects that the practice of $\mathrm{OM}$ is moving away from simple, serial application of techniques towards the implementation of complex, parallel solutions (Wood and Britney, 1988).

Areas which could be covered in OM teaching include field service (Hull and Cox, 1994) and international manufacturing, a current "hot topic" (Klassen and Whybank, 1994). In addition, as in practice OM involves a lot of human resource management, this broader dimension needs to be reflected in teaching (Dreyfus, 1996). However, the adoption of new areas into OM teaching may not be fast enough. A survey of 20 leading schools in the US found that the introduction of new topics such as Total Quality Management was slow (Kaplan, 1991). It is essential that the results of research into current $\mathrm{OM}$ practices are fed back quickly and effectively into teaching (Hill, 1987). In contrast, other authors have warned that the scope of OM courses can be made too wide, bringing with it a danger that courses become unfocused (Bregman and Flores, 1991).

The right balance needs to be struck between including enough new information to demonstrate the topical issues in OM but not trying to cover too many topics. Focus must be given to allocating time to a limited number of key topics which are relevant and stimulating (Bregman and Flores, 1991).

\section{$\underline{\text { Teaching Methods }}$}


A wide range of methods can be used to teach OM including: lectures and case studies; videos; factory visits; practitioners as guest speakers; field projects; and games and simulations. Despite the range of approaches available, a survey of US undergraduate teaching found "the methodologies used to teach the basic POM course have remained very traditional—the lecture approach" (Raizadeh and Ettkin, 1989). Unfortunately Bahl's study of US MBA teaching (Bahl, 1989) did not investigate teaching methods. Consequently, there is only limited evidence on how the different methods are typically used for MBA teaching.

Several authors have pointed to the advantages of particular methods in OM teaching. For example, videos of factories or service operations are an ideal way of bringing realism into the classroom (Nicholson, 1996a). Even popular film clips can be used to illustrate operations management concepts—-for instance Charlie Chaplin's

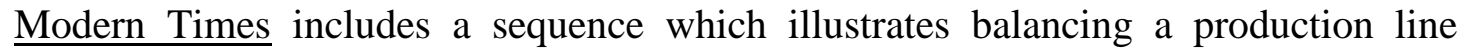
(Schvaneveldt, 1996). Another approach, visits to factories or service operations can provide a useful learning experiences for students (Raizadeh and Ettkin, 1989), particularly if an assignment is based on the visit (Helms, 1989). Guest speakers can bring the "real world" into the classroom and are another way of increasing students' interest in OM (Desai and Inman, 1994). Short field projects are a very effective way of teaching service operations (Armistead and Voss, 1986). Similarly, games and simulations are very useful approaches.

Operations management lends itself to the use of games and simulations which can bring clarity, realism and fun into the classroom. A number of games and simulations have been developed over the years, some of which require the use of computers whereas others are paper-based. 
Morgan (1989) discusses the use of a simulation of a manufacturing plant where small groups of students make operations decisions based on, for example, factory layout and product mix. The advantage of this approach is "students are better able to understand the impact of POM on the other parts of the organisation (and viceversa) and to view POM techniques in their relation to each other rather than as a set of unrelated technical tools". Another example of a paper-based game is an "In-tray Exercise" where, adopting the role of a newly appointed manufacturing manager, students must assess the performance data and mail in their in-tray. Class discussions help students to realise the broad array of issues that are typically faced by a manufacturing manager, including shipment targets, plant layout and statistical process control [(Sohal and Oakland, 1990)(Oakland et al, 1986)]. A number of other games and simulations can be identified in the literature [see, for instance, (Levenburg, 1996), (Pariseau, 1996) and (Julien, 1996)]. Excellent descriptions of over twenty paper-based games are given by Heineke and Meile (1995).

Computer simulations can be used to effectively demonstrate many aspects of OM. For example, an early simulation showed the relationship of OM to other functional areas (Harms and Huff, 1981). Smith developed a computer simulation for demonstrating issues of plant layout and operations planning and control and concluded "simulation remains a powerful tool for the teacher of operations management" (Smith, 1990). A wide range of OM topics can be taught using simulations but one author warns of the difficulties of producing good computer simulations stating, "the operations management teacher must be clear about teaching and learning objectives before designing a microcomputer-based simulation" (Batley, 1991). 
In addition to recognising the advantages of individual teaching methods, Desai and Inman (1994) identify the value of using several methods on one course. They recommend that in addition to case studies, plant tours and guest speakers are necessary to create a more stimulating course. However, it appears that no previous investigations have looked at the balance of methods employed in teaching on MBA core courses.

\section{$\underline{\text { Assessments }}$}

There are two main types of assessments: assessments of the quality of courses and OM faculty (usually surveys of students' views); and assessments of students' performance on OM courses. Interestingly, only the former topic has been discussed in the literature.

Most schools survey their students' views on individual courses and use the results to decide how to make improvements. Normally details are not published but there are a number of exceptions. An alumni survey (Haugen, 1996) showed the need for more case studies, group and computer work on a core POM course. The perceived benefits of studying POM were studied at another institution using a sample of five academic classes, including under- and postgraduates (Ala, 1987). The perceived benefits included: an exposure to manufacturing technologies (such as automation); an understanding of the terminology and; the development of skills necessary to become a general manager.

In a comprehensive study of 366 students, the ratings achieved by POM faculty were investigated. This research identified the problem of surveying students' opinions as a monitor of the effectiveness of OM teachers. "Ratings do not reflect an instructor's ability to help students learn and are not valid measuring devices in terms 
of faculty ability to enhance performance" (Biggs et al, 1991). A better method is required to identify and measure the links between cause (the teacher's ability) and effect (students' learning), although this will be difficult to test empirically.

How are students typically assessed on MBA courses? This question remains open, as apparently it has not been addressed in previous surveys.

\section{$\underline{\text { Integration of OM }}$}

In the OM literature the issue of integration is hardly mentioned and only two references were found to this topic. Klassen and Whybank (1994) stated that teaching international operations management needed a cross-disciplinary approach with team teaching. Gunawardane (1991) recognised that a better understanding was required of how OM could be integrated with other functional area courses effectively.

\section{Perceptions of OM Teaching}

An important topic, judging by the number of times it is discussed in the literature, is the perception of OM courses and claim that OM is not as highly regarded as it should be.

Several pieces of research have investigated both students' and practitioners' perceptions of OM teaching. A survey of under- and postgraduates at a US school examined whether they were biased against POM courses and manufacturing in general (Desai and Inman, 1994). Although the survey was only conducted at one school, the results are nonetheless revealing as student bias against POM was confirmed. Bias resulted from the low image of the subject as it was seen to be linked to manufacturing, and therefore removed from the "real action". Additionally careers in operations were seen as less attractive (ibid). The authors of the study opine that 
business schools place too little emphasis on POM; to rectify this the professional image of the subject needs to be raised by making it more interesting and applicable (ibid). Ala (1987) also claims to have detected student bias against POM but his conclusion can be called into question because of the ambiguity of one of his questions. Students were asked "What is your reason for taking this course?" Because the course was compulsory, most students responded indicating they took the course (only) because they had to. In this case the answers cannot necessarily be taken as an indication of bias, students were possibly responding in a factual manner and not showing bias against the subject.

Several authors conclude from their investigations of OM teaching that the perception of the subject is not as good as it should be. Adler (1989) thinks that more realism and less quantitative methods are needed to improve the image of OM teaching, Ala (1987) believes that OM needs to be promoted more strongly to faculty from other disciplines. Gunawardane (1991) concludes that OM faculty must themselves clearly recognise that OM concepts are not only applicable to production and service operations, if they are going to raise the perception of the subject by demonstrating its wide applicability.

\section{Summary}

Several key themes emerge from the literature which are relevant to the current investigation of MBA teaching at European business schools. These are:

- Course content. A wide variation exists in the topics covered on POM courses in the US. As no European data has been published, investigation is needed to establish whether this is also the case in Europe. In deciding OM course content, the right balance needs to be chosen between strategic and tactical (tools and 
techniques) issues; manufacturing and service operations; and new and traditional material. In other words: "an essential task facing OM faculty is to rethink the mix and emphasis of what is taught in core courses" (Hill, 1996).

- Teaching methods. A wide variety of teaching methods can be employed for OM teaching. Previous investigations of teaching have focused mainly on content and have not investigated the mix of teaching methods adopted.

- Assessment. Both students' and practitioners' assessments of OM courses have been used as inputs to the course design process. However, the other aspect of assessments-how students' performance is assessed-has been ignored in the literature.

- Integration. Almost nothing has been written on how and why OM should be integrated with other subjects, as part of a MBA programme.

- Perceptions. There is some controversy about OM teaching; it needs to cover more than just a collection of tools and techniques. Additionally, it needs to raise the perception of the subject-by making it interesting, relevant and of recognised strategic importance.

\section{RESEARCH METHOD}

The aim of the research was to make an exploratory investigation of how $\mathrm{OM}$ is taught at ten European business schools. To achieve this the following methodology was adopted:

1) The members of faculty responsible for teaching $\mathrm{OM}$ at the schools in the sample were identified by telephoning each school.

2) In May 1996 respondents were personally sent a request by post for an outline of their OM core course. The letter explained the aims of the project and that it was 
being conducted as a project as part of the International Teachers Programme (this was an important factor in gaining the support of respondents). The letter also promised respondents a copy of the results.

3) Follow-up telephone calls were made two weeks later to "remind" respondents to send details of their courses, to further explain the project and to set a mutually convenient date for a telephone interview. These calls established that there was a high level of interest in the survey.

4) The outlines of OM courses from each school were collated and comparison tables prepared. These tables identified where data were not included in the course outlines from particular schools and therefore which needed to be collected during the telephone interviews. The comparison tables also helped generate ideas for general questions for the telephone survey.

5) A questionnaire for the telephone interviews was prepared to collect details of the respondents' OM courses.

6) Telephone interviews were conducted in June-September 1996. Each interview lasted 30 minutes or more and produced substantial data on both respondents' OM courses and their views on teaching.

7) A preliminary report on the findings was sent to respondents in September 1996, to enable them to check the data on their school and to obtain their agreement to publish the results.

\section{Questionnaire Development}

In order to keep the telephone interviews to an acceptable length, it was clear that they needed to focus on key areas only. To establish these, informal discussions were held with six OM faculty from three schools. They were asked which aspects of OM 
teaching at other schools would be of most interest to them and the consensus of their views was strong interest in five areas:

- course content

- teaching methods

- assessment methods

- integration of $\mathrm{OM}$

- faculty's views on challenges in OM teaching.

A standard questionnaire was developed to cover the above points and this is given in Appendix A. As respondents' course outlines had been obtained in advance of the interviews, separate customised versions of the questionnaire were prepared for each interview. These customised questionnaires were annotated with answers that were already known from course outlines (and these were then checked with respondents during the interviews). In addition, it was noted on the customised questionnaires where particular information was required which was not included in the course outline.

The approach used in this research was significantly different to the previous investigations based on postal questionnaires [e.g. (Bahl, 1989),(Raizadeh, 1989)]. As the course outline was obtained in advance, this enabled the researcher to have an understanding of the interviewee's course before the telephone interviews were made. Details of courses were then reviewed with a faculty member during the telephone interviews. This created a rich data set (which included the case studies used, the time allocated to the topic, course reading, etc., etc.) and enabled, for example, the individual sessions on each of the courses to be accurately categorised by their content, even though the sessions in the various courses might have had different titles. 


\section{$\underline{\text { Sample }}$}

The sample was chosen from the Association of MBAs Guide to Business Schools $\underline{1995 / 96}$ listing of recognised schools (Assoc. MBAs, 1995). The choice of schools was not random; instead, a purposive sample was selected according to two criteria. Firstly, rather than selecting a large number of UK schools (34 from the 47 in the AMBA list are UK schools), a number of schools in continental Europe were chosen. Secondly, schools were chosen which are "particularly well-known" and which receive high ratings for their MBA courses in the popular press [see for example (Bickerstaffe, 1996)].

In order to help establish a basis for discussions and comparison, the $\mathrm{OM}$ course at the author's own school was included in the survey. To achieve a comparison of ten schools in total and allow for possible non-response, it was decided to contact a further twelve schools. In the event, this caution proved appropriate as two schools are currently re-designing their core courses and, as a consequence, declined to share information about unfinished and untried designs. In addition, although a faculty member had agreed to participate, one school failed to send details of their course, despite numerous reminders. The ten schools that participated in the survey are identified in the following section. (As a direct result of contacts made during the survey, the author has subsequently had the opportunity to teach at SDA Bocconi and so has first-hand knowledge of two of the OM courses described).

\section{RESULTS}

Table I shows an overview of the OM courses at the ten schools. The first thing to note is that the duration and structure of the MBA courses themselves vary-most are 
one year courses but SDA Bocconi and London Business School (LBS) are longer; 16 and 21 months respectively. The second thing to note is that only eight schools have a OM core course as such. Ashridge's MBA is based on a modular structure (rather than core and elective subjects) but the OM course is compulsory. At Lancaster the introductory $\mathrm{OM}$ course is not compulsory, although it is chosen by approximately $50 \%$ of students.

\section{Insert Table I}

The time allocated to courses varies enormously, from 18 hours (Groupe ESC Lyon) to 76 hours (Bocconi). Partly, this can the accounted for by the different length of the MBA courses at these schools (12 and 16 months respectively). However, the main explanation provided by respondents is that Groupe ESC Lyon has a background of commerce and consequently operations has not traditionally been a main focus of the MBA. Bocconi, on the other hand, has strong contacts with the manufacturing sector and consequently allocates more time to operations. Another possible explanation for the differences in the length of courses is that certain topics are covered by certain schools in electives. However, this is not the main reason for the differences in the length of courses as the range of electives offered by schools is broadly similar (including for example manufacturing strategy, planning and control, etc.) and even the schools offering longer core course also offer further electives. Therefore, time allocated by different schools to teaching the OM core course does vary significantly. The average time allocated is 34 hours; the average across one year MBA courses only is 29 hours. 


\section{$\underline{\text { Course Content }}$}

The course objectives from each schools are given in Table I and these are generally similar; European teaching aims to show the importance operations can play in business performance and to cover some of the key concepts, tools and techniques. The choice of content to achieve these aims was investigated further.

\section{Tools or Strategy?}

The review of the literature demonstrated the need for faculty to strike the right balance between strategic and tactical issues in their teaching of OM. However, it is difficult to identify the correct emphasis which should be placed on strategic issues, as the results show a wide range of variation. From Table I it can be seen that the emphasis on strategic issues may be only $15 \%$, or as high as $50 \%$.

How much strategy should be covered in an OM course? There is some controversy on this. Several respondents commented on the difficulty of choosing the right balance. One stated that it is difficult "trying to balance the strategic and the quantitative". Another indicated that caution is advised when increasing the amount of strategy in a course, saying "the big debate for us on the core programme is how much more strategy to introduce. I see a danger if all the tools and techniques are abandoned ... [the core course needs] a rich mixture of both strategic discussions and tools and techniques". However, another respondent (with already a high percentage of strategy in their course) commented "I think we might even teach more strategy in the future". Although it is not necessarily an indication of the ideal mix, the average across the courses in the sample was a mix of $30 \%$ strategic issues and $70 \%$ tactical tools and techniques. 


\section{Service or Manufacturing?}

Table I shows that more emphasis is placed of manufacturing as opposed to service operations in many courses-on average $66.5 \%$ of course content focuses on manufacturing (with a range from 50 to $90 \%$ ). For instance, Bocconi, with its strong links to manufacturing focuses $90 \%$ of the time on production (but is introducing more focus on service), whereas LBS has an approximately equal mix of service and manufacturing. Ashridge aim to cover all operations management concepts in a "generic" way, explaining them with examples of how they apply in both manufacturing and service situations [similar to the recommendation of Bregman and Flores (1991).

In contrast to the discussions on the difficulty of choosing the right balance between strategic and tactical issues, faculty were much clearer about the right balance between manufacturing and service. Almost all faculty said they wanted to place a higher emphasis on service operations in the future. In most cases they stated the need for equal emphasis, in terms of examples, cases used, time allocated, etc. Several respondents said that their present courses were "still too manufacturing based" and one of the reasons mentioned for this was the shortage of case studies based on service operations which illustrate concepts effectively.

\section{Which OM Topics?}

A check was made on the level of variation between the topics taught at different schools and Table II shows the results. Across all OM courses, 14 major topics were identified, such as the Role of OM, Total Quality Management, Operations Strategy, etc. Table II also shows the number of schools that teach each topic and it can be seen that there is relatively close agreement between the courses. The first seven topics are 
taught by at least $70 \%$ of the ten schools surveyed. This contrasts strongly with the US, where there is much variation in the topics taught (Bahl, 1989). Every European school includes the Role of OM and Total Quality Management in its OM course. The topics Analysing Operations, Inventory Management and Supply Chain Management are taught at eight schools. Surprisingly, considering the discussion in the literature about raising the perceived importance of $\mathrm{OM}$ as a strategically key subject, not every school has a separate session focusing on OM strategy—only seven do-although the other schools say they raise strategic aspects in many sessions.

Insert Table II

Some topics are only taught at a few schools. For instance, new product development is only taught on three courses, whilst at other schools, it is often covered in an elective. Only two schools cover the international aspects of operations in separate sessions. Time-based competition is taught in separate sessions at two schools, although (arguably) it is a form of Business Process Re-Engineering, which is covered on the OM course at four other schools. Project management techniques are discussed at two schools; in most other schools it is a separate course. Only two schools have a separate session on the cost elements of OM.

The textbook used will have an influence on course content. Six schools use either a single or two recommended textbooks (four schools use Slack et al, 1995). Four schools have decided not to recommend textbooks and instead use readings from several books or journal articles (Harvard Business Review articles are commonly used). In order to promote more interest in OM from students with no manufacturing experience, four schools (Ashridge, EAP, INSEAD and Cranfield) recommend that 
students read Goldratt and Cox's novel The Goal, in advance of the course. This book tells the story of a manufacturing manager's struggle to improve his plant's performance and gives a good understanding of manufacturing problems and practices. Appendix 1 gives full details of the textbooks used in courses.

\section{Teaching Methods}

A mix of teaching methods are used on all courses. Every schools uses lectures, case studies and videos in their teaching and, in addition, there is heavy usage of guest speakers, factory visits and games and simulations. Table III summarises the teaching methods used by the ten business schools.

From Table III it can be seen that case studies are used for between $50 \%$ and $88 \%$ of teaching sessions on OM courses. Four schools use comparatively few casesin 50\% of sessions-(Ashridge, Bocconi, EAP, and Groupe ESC Lyon). For instance, Bocconi uses case studies in 19 out of 38 sessions i.e. for approximately $50 \%$ of the teaching time available. In contrast, IMD make the heaviest use of case studies; in 15 out of 17 sessions (approximately $88 \%$ of sessions), whereas the average usage of cases is in $64 \%$ of sessions.

The way in which cases are used was investigated and found to be similar across the schools in the sample. Case studies were seen by OM faculty to be particularly important for two reasons:

- Firstly, faculty thought that for an applied subject like OM, tools and concepts can only be effectively demonstrated within the context of an actual business situation.

- Secondly, the problems faced by operations managers today are complex and so the approaches to solve them, in order to be effective, often involve the use of several concepts or tools in parallel. Students can only start to understand that real 
operations problems are this complex if they have discussed a sufficient number of suitable cases.

Cases are typically used in combination with presentations (on the concepts), plenary discussions and, sometimes students themselves are required to present their conclusions on a case. The cases used in core courses come from a range of sources and "case studies are selected that reinforce a particular concept". There is a heavy reliance on Harvard Business School cases at some schools but every school uses at least one case study which they have developed themselves. IMD, LBS and Warwick all of whom have published a large number of cases, use much of their own material. Cases from IMD, LBS and Warwick are also used at a number of the other schools in the sample.

Videos are used to varying degrees by every school, as shown in Table III. They are used to give students, who often have no experience of manufacturing operations, an idea of the technologies and production layouts. In addition, although students have generally more experience of service operations, faculty say videos are useful to demonstrate in detail how service operations are organised (including back office functions). Several faculty commented that they had difficulty finding enough, up-to-date videos which effectively demonstrate operations issues. To get around this problem, London Business School have obtained access to a number of companies and produced their own videos for teaching purposes. These show manufacturing or service operations, including the technologies involved, and include interviews with operations managers, discussing particular problems or issues. Consequently these videos are used in class as short case studies.

Nine schools use games or simulations to demonstrate operations management techniques, rather than just explaining them. Games and simulations are most 
commonly used for demonstrating inventory control and Just-in-Time techniques. Some of the games used have been published, such as the "Sampson Tiles Game" on forecasting used by Bocconi and Cranfield (Leenders, 1973) and LBS's "Discovery Electronics" (Nicholson, 1996b). Several schools use simple games that they developed themselves but have not published; for instance EAP Paris have a Just-inTime game. One respondent thought that games and simulations would be used more often in the future, as there is "a move towards action-oriented learning activities and away from lectures" at his school. However, another respondent said that games and simulations were only effective for demonstrating tools "and tactical issues" and so thought that their use on MBA core courses had to be limited, if sufficient time was to be allocated to strategic issues.

Most respondents reported that many of their students do not have manufacturing experience. Although videos were felt by faculty to be useful in demonstrating the operations environment, most of them still believed that actual visits were necessary to give students a real "feel for the environment". Consequently, eight schools organise at least one factory visit. Faculty at these schools were all very positive about the advantages of this approach-visits were viewed to be effective at both demonstrating operations and motivating students' interest in OM. Warwick have particularly focused on visits and offer students the chance to visit about a dozen factories (one visit is compulsory). Three schools use guest speakers to add a "firsthand, up to date" view of OM (many of the other schools use the factory visit for this purpose).

\section{Insert Table III}


One innovative approach to teaching — only used by IMD—is to formally have students with an OM background present operations concepts and discuss their own experiences at suitable points in the course. This requires significant preparation, with the teacher reviewing students' c.v.s to determine which student(s) can best contribute on which topic(s). IMD were positive about the results stating, "in fact, the comparison of experiences of different participants about the same issues is the richest learning environmental in operations" (excerpt from the IMD course outline). Although a number of other schools including Groupe ESC Lyon do encourage students to share their experience of managing operations, only IMD emphasise it to the extent that it can account for $40 \%$ of students' marks.

\section{$\underline{\text { Assessments }}$}

How are students on OM courses assessed? In total, the following four different approaches were identified across the schools in the sample:

- Examinations

- Written case assessments

- Project work

- Class participation

Table I gives details of the assessment methods used at each school and it can be seen that every school uses a combination of at least two different types of assessment. In terms of the marks allocated, examinations are the most important method. They are used at every school and, on average $58 \%$ of the total OM marks are allocated to examinations (with a range 30 to $80 \%$ ). Most examinations are based on short case problems. Written assignments also account for a significant amount of the marks on most courses. The types of assignment include case assessments (performed as either 
individual or group work); short projects, such as analysing an operation and making recommendations for improvements (used by Warwick, LBS and Cranfield); and applying techniques and concepts to the participant's own organisation (Ashridge). Class participation is assessed at only three schools (Bocconi, IMD and INSEAD) with the range of marks allocated to this varying from 10 to $70 \%$ of marks. Another assessment method is to have participants with an operations background present their experiences (used by IMD, as explained earlier).

Several OM faculty (respondents) mentioned that they consider it difficult to realistically assess students' performance in OM, as it is such an applied subject. For this reason one respondent was considering giving a higher emphasis to assessment based on project work and stated "examinations are not terribly satisfactory. Projects on, for instance, auditing an operation, give a better measure of students' performance".

\section{Integration with Other Subjects}

Business schools need to "break down the barriers between academic disciplines that prevent many MBA graduates from understanding say, the link between manufacturing and marketing" (Anon, 1992). One school's core course outline even states "a crucial aspect of this subject is the integration with other disciplines, particularly marketing, IT, HRM and Business Policy". However, integration is difficult and one respondent commenting on it said, “That's difficult, we don't do it very well to be honest. With a very international faculty flying in and out, it is somewhat random but we do try and talk [across the disciplines]". Another respondent commented on integration in his school stating that it was; "not very well done 
although, for instance, we know what marketing are doing in parallel. We will be working on more cross-functional approaches".

Some schools try to solve the integration problem in an informal way. For instance by having students give short presentations about experiences which raise relevant cross-functional issues, or $\mathrm{OM}$ teachers discussing points from other disciplines in their sessions: "I address related subjects like marketing and finance [in the OM core course]". At other schools, more formal solutions to the issue of integration come from the MBA course structure itself. For instance:

- One school already uses a significant amount of cross-functional team-teachingin addition to the core OM course where cases are taught from an operations perspective, students have approximately $30 \%$ more cases where cross-functional team-teaching brings out a range of issues.

- Another school has an ambitious project to change its curriculum, so that half of the teaching will be fully integrative, with 2-3 teachers co-teaching complex cases. Suitable cases are currently being prepared by teams of cross-functional teachers (including OM faculty).

- Several schools have cross-functional electives.

- Most schools stress that MBA projects should be approached in a cross-functional way.

Several of the schools surveyed are currently focusing on integration and it was identified as a key issue by most respondents.

\section{Challenges in OM Teaching}

The respondents, all of whom regularly teach core courses, were asked their opinion on the challenges in $\mathrm{OM}$ teaching - and all expressed particular interest in the results 
of this part of the research. The issues raised can be grouped into three broad categories:

- Difficulties with the scope of the subject itself

- Concern on how best to demonstrate the importance and relevance of $\mathrm{OM}$

- The complexity of teaching an applied, constantly changing subject.

Several faculty did not think that operations was a sufficiently well-defined subject and commented, for example, "I still think the biggest challenge is definition; I am far from satisfied that we actually know what operations is" or, "the challenge is to define our subject from [the current] rat-bag of tools". Another respondent said it was a challenge "trying to give structure to a course consisting of lots of diverse tools and techniques".

How can the wider relevance of $\mathrm{OM}$ be demonstrated and students convinced of its importance? One respondent was of the opinion that "students are increasingly convinced that operations is important, I think the tables are turning in our favour". However, most respondents commented on the difficulties of trying to "get people to recognise that OM tools and techniques are useful in many situations". One stated, "I think the biggest challenge is to grow our subject area and the key is relevance. Teaching has to be highly relevant..." and continued to say that, in addition, OM teachers must "teach the magic of the area". Another said "the biggest challenge is to be in touch with reality and know what it is relevant to teach (to managers who have come from industry and know what is important)". One respondent noted the problem of relevance also existed in executive education saying "executives don't see the key importance of operations". Several respondents said that the strategic side of OM must be even more strongly emphasised if students are to be convinced of its importance. 
Respondents said their courses required constant revision to include the latest ideas: "we think that the challenges are covering supply chain integration; the virtual organisation; time-based competition and; out-sourcing but still covering JIT, TQM and other topics well". One respondent said the biggest challenge was "keeping up with the changes in technology: scurrying around trying to keep up is the biggest frustration, as it takes some much time".

\section{CONCLUSIONS}

This research was the first investigation of European OM teaching on MBA courses. Although the methodology used was comparatively simple, the results are important and conclusions can be drawn on two levels. Firstly, direct conclusions can be drawn from comparing the different courses and their content; secondly, conclusions can be reached from the issues raised by respondents and the need for more detailed research into OM teaching issues.

On the primary level, the survey results give useful insights in five key areas:

- Course content. Although there is strong agreement between European schools on course content, there are significant variations on three dimensions: the time allocated to OM; the emphasis placed by OM faculty on strategic or tactical issues; and the relative focus on manufacturing or service operations.

The time allocated to OM varied widely. From discussions with respondents, it appears that 25-30 hours is generally viewed as appropriate for teaching OM on one-year MBA programmes-in order to achieve the twin goals of showing the importance of operations and covering some of the key tools and techniques. (One respondent even said he will be using the results of the survey to convince his school to allocate more time to OM!) 
The amount of strategy included in core courses ranged from 15 to $50 \%$. Most faculty thought that it was important to include a significant amount of strategy to capture students' interest but found it difficult to decide exactly how much was required. Taking an average across the sample, a 30\% focus on strategy, as opposed to tools and techniques, is used. However, this figure does not necessarily indicate the correct mix - further research would be required to investigate the complex issue of the ideal amount of strategy to be included in the core course.

Several schools still have a stronger focus on manufacturing than on service operations. The consensus of the respondents was that parity between service and manufacturing operations is highly desirable in core courses. However, most schools have some way to go to achieving this and good material, especially case studies, is scarce.

- Teaching methods. A wide variety of teaching methods can be employed for OM teaching. The survey showed a strong similarity in the teaching methods adopted across schools. It could be concluded that this indicates that all schools are adopting the right approach. However, on the other hand, it could be said that there is room for more innovation in OM teaching. Indeed, significant innovation may be required if the key challenges facing OM teachers are to be addressed. For instance, since $\mathrm{OM}$ is such an applied subject, maybe some elements of action-based learning are required even on core courses.

- Assessment. The survey results are the first data on how students are assessed. They indicate that faculty think that a combination of at least two methods are desirable on core courses. Further research would be required to probe the effectiveness of the different assessment methods, or their combinations. 
- Integration. Although integration is perceived by faculty to be an important issue, the results show that most schools are only just starting to investigate formal ways to approach this problem. OM faculty, as they perceive this issue as important, should take an active role in the moves towards integration at their schools.

- Perceptions. From respondents' views, it appears that OM faculty are facing two fundamental challenges. These are the need to develop a clearer structure for the subject and to become more effective at demonstrating its wider relevance. Although the current study only provides anecdotal evidence of these key challenges, these do mirror some of the concerns about OM teaching raised in the literature. Perhaps, OM teachers in general "still seem to consider POM as the key user of these concepts and skills" (Gunawardane, 1991) and do not focus on showing the wider relevance for the tools and techniques. Certainly the majority of OM case studies demonstrate how the tools and techniques can be applied in a manufacturing or a service environment. Therefore, it can be concluded that there is a real need for research and good case material which demonstrates how $\mathrm{OM}$ concepts are useful to not only operations managers but also managers in all functional areas.

To raise the perceived importance of their subject, OM faculty face a difficult challenge and they must be proactive in looking for ways to do this. Many schools are currently revising their MBA programmes and, in particular there is much discussion on integration. OM teachers must be active in influencing how integration will be achieved and in setting $\mathrm{OM}$ at the centre of these programmes. It is, in the author's opinion, an opportunity to be grasped by, for example, OM teachers taking a leading role in developing suitable cross-functional cases. Because, if OM continues to be associated with 'just manufacturing' or 'just 
manufacturing and services', then the perception of the subject will not be enhanced.

The broadest conclusion on the research is that-as the first investigation of OM teaching on MBA courses in Europe-it was long overdue and demonstrates that too little emphasis has previously been placed on this area. The author hopes that this paper will trigger wider discussions on and deeper research into OM teaching. This is certainly necessary because of the fundamental nature of some of the issues raised by respondents—-particularly the problems with the definition of $\mathrm{OM}$ and its perceived relevance. These are issues which urgently need to be addressed if the standing of operations management is to be enhanced through teaching.

\section{ACKNOWLEDGEMENTS}

The author would like to thank the operations management faculty who responded to the survey: Stuart Chambers (Warwick), Carlos Cordon (IMD), Alberto Grando (SDA Bocconi), Terry Hill (LBS), John Mapes (Cranfield), Nick Middle and Anthony Mitchell (Ashridge), Mike Pidd (Lancaster), John Smith (EAP Paris), Luk Van Wassenhove and Enver Yucasan (INSEAD) and Derek Waller (Groupe ESC Lyon). 
 \\ European Operations Management MBA Core Courses}

\section{Section One Details of Institution / Respondent}

Institution

Date.
Respondent

Time (start)

(finish)

\section{Section Two Full-Time MBA Course Details \\ (answers largely determined from MBA publications prior to interview)}

Length of course.

Core + electives or modular.

Is operations management compulsory?

[ ] Yes [ ] No: comments

\section{Section Three - The Operations Management Core Course}

(answers partly determined from course outlines obtained prior to interview)

Number / length of sessions.

Topics covered by session.

Mix of strategy / tools and techniques

from course outline (estimate)

from interview.

Mix of manufacturing / service (\%)

from course outline (estimate)

from interview.

Textbook(s)

Teaching methods used

Lectures [ ] Yes Notes on usage.

Case studies [ ] Yes Notes on usage.

Videos [ ] Yes Notes on usage

Speakers [ ] Yes Notes on usage

Games etc. [ ] Yes Notes on usage 
Visits [ ] Yes Notes on usage

Other [ ] Yes Notes on usage

Section Four - Assessment Methods

What type(s) of assessment methods are used?

\begin{tabular}{|c|c|}
\hline Exams. [ ] Yes & $\begin{array}{l}\text { Percentage... } \\
\text { Notes............ }\end{array}$ \\
\hline Assignments [ ] Yes & $\begin{array}{l}\text { Percentage... } \\
\text { Notes............ }\end{array}$ \\
\hline Project work [ ] Yes & $\begin{array}{l}\text { Percentage... } \\
\text { Notes............ }\end{array}$ \\
\hline Class partic. [ ] Yes & $\begin{array}{l}\text { Percentage... } \\
\text { Notes...................... }\end{array}$ \\
\hline
\end{tabular}

Have you any additional comments on assessing operations management?

..(details / length)

\section{Section Six - Integration}

How is operations management integrated with other disciplines?

\section{Section Seven - Challenges in OM Teaching}

What do you think is the biggest challenge facing operations management teachers?

Which aspects of your OM courses do you intend to change in the next 2 - 3 years? 


\section{APPENDIX B}

The books used on OM courses and referred to in the text and Table I are:

1. Grando, A. Organizzazione e Gestione della Produzione Industriale. EGEA Milan, 1995.

2. Goldratt, E.M. and Cox, J. The Goal. North River Press, 1986.

3. Render, B. and Heizer, J. Principles of Operations Management: Building and Managing World-Class Operations. Alleyn and Baco, Boston, 1994.

4. Slack, N., Chambers, S., Harland, C., Harrison, A. and Johnston, R. Operations Management. Pitman, London 1995.

5. Schonberger, R.J. and Knod, E.M. Operations Management: Improving Customer Service. Irwin, Boston, 4th ed. 1994.

6. Vollman, T.E., Berry, W.L. and Whybark, C.D. Manufacturing Planning and Control Systems. 2nd ed. Irwin, Illinois, 1988. 


\section{REFERENCES}

1. Adler, P.S. (1989), "When Knowledge Is the Critical Resource, Knowledge Management Is the Critical Task", IEEE Transactions on Engineering Management, Vol. 36, No. 2, pp. 87-94.

2. Ala, M. (1987), "How Students Perceive the Benefits of Studying Production and Operations Management", Production \& Inventory Management J., Vol. 28, No. 4, pp. 71-74.

3. Anonymous (1992), "Management Focus: On Harvard's Heels - New Business Schools at Oxford and Cambridge Promise Fresh Methods of Management Education. Can They Deliver?", The Economist, Vol. 324, No. 7770, 1st August, p.117.

4. Armistead, C; Johnston, R; Voss, C. A. (1986), "Introducing Service Industries in Operations Management Teaching", International Journal of Operations \& Production Management, Vol. 6, No. 3, pp. 21-29.

5. Association of MBAs [AMBA] (1995), Guide to Business Schools 1995/6. Financial Times Pitman, London, p. 52.

6. Bahl, H.C. (1989), "Teaching Production and Operations Management at the MBA Level - A Survey", Production \& Inventory Management Journal, Vol. 30, No. 3, (Third Quarter), pp. 5-7.

7. Batley, T. W. (1991), "Microcomputer Simulation for Teaching Operations Management", International Journal of Operations \& Production Management, Vol. 11, No. 1, pp. 5-13.

8. Berry, S. (1979), "Practitioners' Views on the Importance of Selected Production Management Topics", Production \& Inventory Management Journal, Vol. 21, No. 3, pp. 1-17.

9. Bickerstaffe, G. (1996), Which MBA? A Critical Guide to the World's Best Programmes, Addison Wesley-Longman, Harlow, UK.

10. Biggs, J.R., Campion, W.M. and Gosenpud, J.J. (1991), “The Student Evaluation of Instructors in required Operations Management Courses", Operations Management Review, Vol. 8, No. 2, pp. 14-30.

11. Bowen, K. (1996), "Teaching 800 MBAs Technology and Operations Management", Proceedings of the Conference on Teaching POM: Visions, Topics and Pedagogies [7th Annual Meeting of the Production and Operations Management Society], April 1-2, Indianapolis, USA, p. A22.

12. Bregman, R.L. and Flores, B.E. (1991), "OM Curriculum: Challenges for the 1990's, and Beyond”, Operations Management Review, Vol. 8, No. 2, pp. 47-55.

13. Chand, S. (1996), "Teaching Operations Core: Goals, Teaching Materials and Organization", Proceedings of the Conference on Teaching POM: Visions, Topics and Pedagogies [7th Annual Meeting of the Production and Operations Management Society], April 1-2, Indianapolis, USA, p.10.

14. Davies, H. (1996), "Reflect Real Life: Teach Operations Through Drivers Not Techniques", Proceedings of the Conference on Teaching POM: Visions, Topics and Pedagogies [7th Annual Meeting of the Production and Operations Management Society], April 1-2, Indianapolis, USA, p. 2.

15. Desai, K. and Inman, R.A. (1994), "Student Bias against POM Coursework and Manufacturing", International Journal of Operations and Production Management, Vol. 14, No. 8, pp. 70-87.

16. Donohue, K. (1996), "OM Core Courses at The Wharton School”, Proceedings of the Conference on Teaching POM: Visions, Topics and Pedagogies [7th Annual 
Meeting of the Production and Operations Management Society], April 1-2, Indianapolis, USA, p. A22.

17. Dreyfus, P. (1996), “A POM Educational Dimension”, Proceedings of the Conference on Teaching POM: Visions, Topics and Pedagogies [7th Annual Meeting of the Production and Operations Management Society], April 1-2, Indianapolis, USA, p. 2.

18. Ducharme, R.E. (1991), "Eliminate the OM Major? A Challenge for the Operations Management Association!", Operations Management Review, Vol. 8, No. 2, pp. 8-13.

19. Frazer, C.L. (1996), "Practitioners' Perspectives and the Core Course", Proceedings of the Conference on Teaching POM: Visions, Topics and Pedagogies [7th Annual Meeting of the Production and Operations Management Society], April 1-2, Indianapolis, USA, p. 14.

20. Gunawardane, G. (1991), "Trends in Teaching Management Science in Undergraduate Business Programs", Interfaces, Vol. 21, No. 5, pp. 16-21.

21. Harms, C.G and Huff, S.W. (1981), "The Harms Shoe Company: Development of a Computer Model for the Classroom”, Decision Sciences, Vol. 12, No. 4, pp. 670689.

22. Haugen, D.L. (1996), "Improving the MBA Operations Course", Proceedings of the Conference on Teaching POM: Visions, Topics and Pedagogies [7th Annual Meeting of the Production and Operations Management Society], April 1-2, Indianapolis, USA, p. 5.

23. Heineke, J.N. and Meile, L.C. (1995), Games and Exercises for Operations Management: Hands-on Learning Activities for Basic Concepts and Tools, Prentice Hall International, New Jersey.

24. Helms, M.M. (1989), "To Produce Interest in Production, Just Open the Factory Door", Production and Inventory Management Journal, Second Quarter 1989, pp. 72-73.

25. Hill, T.J. (1996), "Manufacturing Strategy: Keeping it Relevant by Addressing the Needs of the Market", Manuscript of Opening Address, 3rd Conference of the European Operations Management Association (EurOMA), June 1996, London.

26. Hill, T.J. (1987), "Teaching and Research Directions in Production / Operations Management: The Manufacturing Sector", International Journal of Operations \& Production Management, Vol. 7, No. 4, pp. 5-12.

27. Hull, D.L and Cox, J.F. (1994), "The Field Service Function in the Electronics Industry: Providing a Link between Customers and Production/Marketing”, International Journal of Production Economics, Vol. 37, No. 1, pp. 115-126.

28. Julien, F.M. (1996), "Integrating Logistics Planning Activities with SIMLOG", Proceedings of the Conference on Teaching POM: Visions, Topics and Pedagogies [7th Annual Meeting of the Production and Operations Management Society], April 1-2, Indianapolis, USA, p.10.

29. Kaplan, R.S. (1991), "The Topic of Quality in Business School Education and Research", Selections, Autumn, pp. 13-21.

30. Killeya, J.C and Armistead, C.G. (1983), "The Transfer of Concepts and Techniques Between Manufacturing and Service Systems", International Journal of Operations \& Production Management, Vol. 3, No. 3, pp. 22-28.

31. Klassen, R.D. and Whybark, D.C. (1994), "Barriers to the Management of International Operations”, Journal of Operations Management, Vol. 11, No. 4, pp. 385-396. 
32. Leenders, M. (1973), Sampson Sewer Tile Production Game. University of Western Ontario.

33. Levenburg, N. (1996), "What the Customer Wants: Reengineering the POM Programme". Proceedings of the Conference on Teaching POM: Visions, Topics and Pedagogies [7th Annual Meeting of the Production and Operations Management Society], April 1-2, Indianapolis, USA, p.12.

34. Morgan, C.L. (1989), "Achieving Academic and Practitioner Objectives in the Basic POM Survey Course", Production \& Inventory Management, Vol. 30, No. 2 , pp. 48-51.

35. Nicholson, A. (1996a), "POM as the Systems Which Link Commercial Value and Daily Working Practices". Proceedings of the Conference on Teaching POM: Visions, Topics and Pedagogies [7th Annual Meeting of the Production and Operations Management Society], April 1-2, Indianapolis, USA, p. 2.

36. Nicholson, A. (1996b), "The Sticklebrick Experiment: Experiencing Real Operations", Proceedings of the Conference on Teaching POM: Visions, Topics and Pedagogies [7th Annual Meeting of the Production and Operations Management Society], April 1-2, Indianapolis, USA, p. 7.

37. Oakland, J.S., Lockyer, K.G. and Sohal, A. (1986), "The Incident Case Study in Teaching Production Control", Production and Inventory Management Journal, Vol. 27, No. 2, pp. 48-57.

38. Pariseau, S.E. (1996), "Redesigning the POM Core Course", Proceedings of the Conference on Teaching POM: Visions, Topics and Pedagogies [7th Annual Meeting of the Production and Operations Management Society], April 1-2, Indianapolis, USA, p. 10.

39. Raiszadeh, F.M.E and Ettkin, L.P. (1989), "POM in Academia: Some Causes for Concern”, Production \& Inventory Management Journal, Vol. 30, No. 2, pp. 3740.

40. Schvaneveldt, S.J. (1996), "Teaching Operations Management with Popular Film Scenes: List of Selected Film Scenes", Proceedings of the Conference on Teaching POM: Visions, Topics and Pedagogies [7th Annual Meeting of the Production and Operations Management Society], April 1-2, Indianapolis, USA, p. A29.

41. Smith, D. J. (1990), "The Use of Microcomputer-Based Simulation Models in the Teaching of Operations Management", International Journal of Operations \& Production Management, Vol. 10, No. 5, pp. 5-14.

42. Sohal, A.S. and Oakland, J.S. (1990), "Teaching Production and Operations Management Through Participative Methods", Production \& Inventory Management Journal, Vol. 31, No. 3, pp. 30-34.

43. White, C.R., Adams, J., Donehoo, K. and Hofacher, S. (1988), "Educational and Systems Requirements for Production Control”, Production and Inventory Management Journal, Vol. 29, No. 2, pp. 10-12.

44. Willis, T.H. and Bass, K. (1991), "A Profile of Academic Offerings in Production / Operations Management”, Operations Management Review, Vol. 8, No. 2, pp. 3642.

45. Wood, A.R. and Britney, R.R. (1988/89), "Production Operations Management: Research and teaching Opportunities in the 1990's", Operations Management Review, Vol. 7, No. 2, Fall 1988 and Winter 1989, pp. 33-42. 
Table I: Overview of the OM "Core Courses" Reviewed ${ }^{1}$

\begin{tabular}{|c|c|c|c|c|c|c|c|}
\hline$\#$ & $\begin{array}{c}\text { School / Location / Type of MBA } \\
\text { Course }^{2}\end{array}$ & $\begin{array}{c}\text { Set } \\
\text { Course } \\
?\end{array}$ & $\begin{array}{l}\text { Sessions / } \\
\text { Duration }\end{array}$ & Course Objectives & $\begin{array}{c}\text { Focus of Course } \\
\text { (approx.) } / \\
\text { Main text }\end{array}$ & $\begin{array}{l}\text { Assessment } \\
\text { Method(s) }\end{array}$ & \\
\hline 1. & $\begin{array}{l}\text { Ashridge Management College, UK } \\
\text { / One year "Modular" MBA }\end{array}$ & Yes & $\begin{array}{l}12 \text { sessions } \\
\text { Total } 51 \\
\text { hours }\end{array}$ & $\begin{array}{l}\text { 1. To understand the key issues in effective OM; } 2 \text {. Develop an ability to } \\
\text { analyse service /manufacturing operations; } 3 \text {. To review the different } \\
\text { approaches to planning and controlling of service /manufacturing } \\
\text { operations; } \\
4 \text {. Understand the contribution, philosophy and approaches to TQM } \\
\text { implementation; } 5 \text {. An awareness of how to implement new products, } \\
\text { processes or technology }\end{array}$ & $\begin{array}{l}60 \% \text { manufacturing } \\
40 \% \text { service } \\
35 \% \text { strategy } \\
65 \% \text { tactical issues } \\
\text { Text: various } \\
\text { readings }\end{array}$ & $\begin{array}{l}\text { Examination } 33 \% \text {; } \\
2 \text { written assignments, } \\
\text { each } 33 \% \text { (applying } \\
\text { selected frameworks } \\
\text { to the participant's } \\
\text { organisation; practice } \\
\text { of problem solving } \\
\text { techniques) }\end{array}$ & 1 \\
\hline 2. & $\begin{array}{l}\text { SDA Bocconi, Milan, Italy / } 16 \\
\text { month full-time MBA }\end{array}$ & Yes & $\begin{array}{c}38 \text { sessions } \\
\text { Total } 76 \\
\text { hours }\end{array}$ & $\begin{array}{l}\text { 1. To investigate the role of OM in different manufacturing processes; } 2 \text {. } \\
\text { To provide tools for an integrated performance measurement system; } 3 \text {. To } \\
\text { develop an ability to analyze and solve typical OM problems: logistics, } \\
\text { quality, production planning, stock control, purchasing, etc. }\end{array}$ & $\begin{array}{l}90 \% \text { manufacturing } \\
10 \% \text { service } \\
20 \% \text { strategy } \\
80 \% \text { tactical issues } \\
\text { Text: Vollman et al } \\
\text { [1998], Grando } \\
{[1995]}\end{array}$ & $\begin{array}{l}\text { Examination } 80 \% \\
\text { Written case assess } \\
10 \% \\
\text { Class participation } \\
10 \%\end{array}$ & 2 \\
\hline 3. & $\begin{array}{l}\text { Cranfield School of Management, } \\
\text { UK / One year full-time MBA }\end{array}$ & Yes & $\begin{array}{l}25 \text { sessions } \\
\text { of } 1 \text { hour } \\
\text { Total } 25 \\
\text { hours }\end{array}$ & $\begin{array}{l}\text { 1. To provide an understanding of the operations management task and the } \\
\text { trade-offs involved } \\
\text { 2. To develop skills in analyzing and improving product and service } \\
\text { delivery systems } \\
\text { 3. To develop an understanding of the impact of other functional areas on } \\
\text { operations management }\end{array}$ & $\begin{array}{l}60 \% \text { manufacturing } \\
40 \% \text { service } \\
30 \% \text { strategy } \\
70 \% \text { tactical issues } \\
\text { Text: Slack et al } \\
\text { [1995] }\end{array}$ & $\begin{array}{l}\text { Examination } 50 \% \text {; } \\
\text { Written (group) case } \\
\text { assess } 25 \% \text {; } \\
\text { Short project } \\
\text { analyzing a service } \\
\text { operation } 25 \%\end{array}$ & 3 \\
\hline 4. & $\begin{array}{l}\text { EAP_-Ecole Européenne des } \\
\text { Affaires, Paris, France / One year } \\
\text { full-time MBA }\end{array}$ & Yes & $\begin{array}{l}12 \text { sessions } \\
\text { of } 3 \text { hours } \\
\text { Total } 36 \\
\text { hours }\end{array}$ & $\begin{array}{l}\text { 1. To investigate and analyse the role of OM in an international context } \\
\text { 2. To widen participants' appreciation of the criteria of measuring } \\
\text { operational performance } \\
\text { 3. To expose participants to a range of international operational issues, } \\
\text { problems and a number of current concepts and techniques }\end{array}$ & $\begin{array}{l}60-70 \% \\
\text { manufacturing } \\
40-30 \% \text { service } \\
20 \% \text { strategy } \\
80 \% \text { tactical issues }\end{array}$ & $\begin{array}{l}\text { Examination } 70 \% \text {; } \\
\text { Assessment of cases } \\
\text { and participation } 30 \%\end{array}$ & 4 \\
\hline
\end{tabular}




\begin{tabular}{|c|c|c|c|c|c|c|c|}
\hline & & & & & $\begin{array}{l}\text { Text: Slack et al } \\
{[1995]}\end{array}$ & & \\
\hline 5. & $\begin{array}{l}\text { IMD-International Institute for } \\
\text { Management Development, } \\
\text { Lausanne, Switzerland / One year } \\
\text { full-time MBA }\end{array}$ & Yes & $\begin{array}{l}17 \text { sessions } \\
\text { of } 1.3 \text { hours } \\
\text { Total } 22 \\
\text { hours }\end{array}$ & $\begin{array}{l}\text { 1. To introduce the most important concepts of OM } \\
\text { 2. To provide a general management perspective of those issues that a } \\
\text { general manager is going to require to deal with }\end{array}$ & $\begin{array}{l}70 \% \text { manufacturing } \\
30 \% \text { service } \\
50 \% \text { strategy } \\
50 \% \text { tactical issues } \\
\text { Text: various } \\
\text { readings }\end{array}$ & $\begin{array}{l}\text { Examination } 30 \% \text {; } \\
\text { Class participation } 30- \\
70 \%{ }^{7} \text {; } \\
\text { Selected participants' } \\
\text { presentations } 40 \%\end{array}$ & 5 \\
\hline 6. & $\begin{array}{l}\text { INSEAD_European Institute of } \\
\text { Business Administration, } \\
\text { Fontainbleau, France / One year } \\
\text { full-time MBA }\end{array}$ & Yes & $\begin{array}{l}16 \text { sessions } \\
\text { of } 1 \frac{1 / 2}{2} \text { hours } \\
\text { Total } 24 \\
\text { hours }\end{array}$ & $\begin{array}{l}\text { 1. To improve understanding of operational problems and their strategic } \\
\text { importance } \\
\text { 2. To provide participants with some analytical tools (which can also be } \\
\text { applied to problems outside operations) }\end{array}$ & $\begin{array}{l}80 \% \text { manufacturing } \\
20 \% \text { service } \\
30 \% \text { strategic } \\
70 \% \text { tactical } \\
\text { Text: various } \\
\text { readings }\end{array}$ & $\begin{array}{l}\text { Examination } 80 \% \text {; } \\
\text { Class participation } \\
10 \% \text {; } \\
\text { Short written } \\
\text { assessment of cases } \\
10 \%\end{array}$ & 6 \\
\hline 7. & $\begin{array}{l}\text { Lancaster University-The } \\
\text { Management School, UK / One } \\
\text { year full-time MBA }\end{array}$ & $\begin{array}{l}\text { No: } \\
\text { elective } \\
\text { course }\end{array}$ & $\begin{array}{l}9 \text { sessions } \\
\text { of } 4 \text { hours. } \\
\text { Total } 36 \\
\text { hours }\end{array}$ & $\begin{array}{l}\text { 1. To provide a general overview of the main ideas of contemporary } \mathrm{OM} \text { as } \\
\text { applied to both the service and manufacturing sectors } \\
2 \text {. To provide a basis for further study and the MBA project work }\end{array}$ & $\begin{array}{l}65 \% \text { manufacturing } \\
35 \% \text { service } \\
35 \% \text { strategy } \\
65 \% \text { tactical issues } \\
\text { Text: Schonberger } \\
\& \text { Knoll [1994] }\end{array}$ & $\begin{array}{l}\text { Examination } 50 \% \text {; } \\
\text { Course work } 50 \% \\
\text { (mainly case } \\
\text { assessments) }\end{array}$ & 7 \\
\hline 8. & $\begin{array}{l}\text { London Business School, London } \\
\text { UK / } 21 \text { month full-time MBA }\end{array}$ & Yes & $\begin{array}{l}10 \text { sessions } \\
\text { Total } 30 \\
\text { hours }\end{array}$ & $\begin{array}{l}\text { To understand: } \\
\text { 1. The scope and significance of OM in varied manufacturing and service } \\
\text { contexts } \\
\text { 2. How OM contributes to the way a firm competes in the market place and } \\
\text { achieves commercial results } \\
\text { 3. How to analyse an operation and improve its effectiveness } \\
\text { 4. The role of certain techniques and approaches in operations, and the } \\
\text { managerial issues surrounding them }\end{array}$ & $\begin{array}{l}50 \% \text { manufacturing } \\
50 \% \text { service } \\
40 \% \text { strategy } \\
60 \% \text { tactical issues } \\
\text { Text: Slack et al } \\
\text { [1995] }\end{array}$ & $\begin{array}{l}\text { Examination } 50 \% \text {; } \\
\text { Group project } 30 \% \text {; } \\
\text { Group case } \\
\text { assessments } 20 \%\end{array}$ & 8 \\
\hline 9. & $\begin{array}{l}\text { Groupe ESC Lyon, France / One } \\
\text { year full-time MBA }\end{array}$ & Yes & $\begin{array}{l}12 \text { sessions } \\
\text { of } 1 \frac{1 / 2}{2} \text { hours } \\
\text { Total } 18 \\
\text { hours }\end{array}$ & $\begin{array}{l}\text { 1. To illustrate the key elements in the OM environment } \\
\text { 2. How elements must be considered as an integrated system } \\
\text { 3. Operations impact on the strategy of the firm }\end{array}$ & $\begin{array}{l}70 \% \text { manufacturing } \\
30 \% \text { service } \\
15 \% \text { strategy }\end{array}$ & $\begin{array}{l}\text { Examination } 80 \% \text {; } \\
\text { Case assessment } \\
\text { (written/aural) } 20 \%\end{array}$ & 9 \\
\hline
\end{tabular}




\begin{tabular}{|c|c|c|c|c|c|c|c|}
\hline & & & & & $\begin{array}{l}85 \% \text { tactical issues } \\
\text { Text: Render and } \\
\text { Heizer [1994] }\end{array}$ & & \\
\hline \multirow[t]{2}{*}{10.} & $\begin{array}{l}\text { Warwick Business School, } \\
\text { Coventry UK / One year full-time } \\
\text { MBA }\end{array}$ & Yes & $\begin{array}{l}10 \text { sessions } \\
\text { Total } 28 \\
\text { hours }\end{array}$ & $\begin{array}{l}\text { 1. To enable you to appreciate the important strategic role of operations in } \\
\text { today's manufacturing and service enterprises; } 2 \text {. To help you understand } \\
\text { and manage the critical interfaces between operations and other business } \\
\text { functions; } 3 \text {. To give you an understanding of, and limited analytical skills } \\
\text { in using operations management tools and concepts; } 4 \text {. To show you how } \\
\text { some of these ideas could be applied in almost any function in businesses } \\
\text { and not-for-profit organisations. }\end{array}$ & $\begin{array}{l}55 \% \text { manufacturing } \\
45 \% \text { service } \\
30 \% \text { strategy } \\
70 \% \text { tactical issues } \\
\text { Text: Slack et al } \\
\text { [1995] }\end{array}$ & $\begin{array}{l}\text { Examination } 60 \% ; \\
\text { Group projects } 40 \%\end{array}$ & $\begin{array}{l}1 \\
0\end{array}$ \\
\hline & & & $\begin{array}{l}\text { Average }= \\
34 \text { hours }\end{array}$ & & & & \\
\hline \multicolumn{8}{|c|}{$\begin{array}{l}\text { Notes: } \\
1 \text { Some MBA courses are not designed as core and elective courses and so the term "core course" is used loosely. } \\
2 \text { Most schools offer one than one MBA programme and so the specific course surveyed is indicated. Some differences may exist in the OM courses taught on other MBA programmes at the same school. } \\
3 \text { The focus of the course between manufacturing and service, strategic and tactical issues are approximate percentages derived from reviewing course outlines and discussions with respondents. } \\
4 \text { Full references to the textbooks are given in Appendix A. } \\
5 \text { Note: all schools use lectures, cases and videos in their teaching. Supplementary methods are also shown. } \\
6 \text { EAP adjust the balance between manufacturing and service according to the interests of each class. } \\
7 \text { Selected IMD students with relevant OM experience present to classes and are assessed on this (40\%). Students without OM experience are assessed more heavily on their class participation. }\end{array}$} \\
\hline
\end{tabular}


Table II: Course Content on Ten European “Core” MBA Courses.

\begin{tabular}{|c|c|c|c|}
\hline & Topic $^{1}$ & Details / Examples & $\begin{array}{c}\text { Number of } \\
\text { schools }\end{array}$ \\
\hline 1. & $\begin{array}{l}\text { The Role of Operations } \\
\text { Management }\end{array}$ & $\begin{array}{l}\text { Introduction to the subject, the role of operations } \\
\text { in services and manufacturing. Role of operations } \\
\text { managers }\end{array}$ & 10 \\
\hline 2. & $\begin{array}{l}\text { Total Quality Management } \\
\text { (TQM) }\end{array}$ & Philosophy of TQM, quality tools, etc. & 10 \\
\hline 3. & Analysing operations & $\begin{array}{l}\text { Process design, process flow and volume/variety } \\
\text { etc. }\end{array}$ & 8 \\
\hline 4. & $\begin{array}{l}\text { Supply Chain } \\
\text { Management }\end{array}$ & $\begin{array}{l}\text { Make or buy decisions, buyer / supplier } \\
\text { relationships }\end{array}$ & 8 \\
\hline 5. & Inventory Management & Types of inventory, control, Just-in-Time (JIT) & 8 \\
\hline 6. & Operations Strategy & $\begin{array}{l}\text { How operations is essential in both influencing } \\
\text { and implementing business strategy }\end{array}$ & 7 \\
\hline 7. & Capacity Management & $\begin{array}{l}\text { Capacity: concept and strategies, bottleneck } \\
\text { management, etc. }\end{array}$ & 7 \\
\hline 8. & Planning and Control & Types of demand, forecasting demand, etc. & 6 \\
\hline 9. & $\begin{array}{l}\text { Business Process Re- } \\
\text { engineering }\end{array}$ & $\begin{array}{l}\text { Process analysis, measurement metrics, process } \\
\text { redesign }\end{array}$ & 4 \\
\hline 10 . & $\begin{array}{l}\text { New Product / Process } \\
\text { Development }\end{array}$ & $\begin{array}{l}\text { Time-to-market, simultaneous engineering, } \\
\text { Quality Function Deployment }\end{array}$ & 3 \\
\hline 11. & Project Management & Techniques & 2 \\
\hline 12. & $\begin{array}{l}\text { Issues for International } \\
\text { Operations }\end{array}$ & $\begin{array}{l}\text { Facility location, aspects of international } \\
\text { manufacturing and service operations. }\end{array}$ & 2 \\
\hline 13. & Time-Based Competition & $\begin{array}{l}\text { Time as a competitive element, time issues in } \\
\text { manufacturing and service operations. Estimating } \\
\text { production costs, financial auditing of operations. }\end{array}$ & 2 \\
\hline 14. & Cost elements & $\begin{array}{l}\text { Estimating production costs, financial auditing of } \\
\text { operations. }\end{array}$ & 2 \\
\hline
\end{tabular}

Notes: 1 The topics in actual courses often had different titles but have been grouped into categories 2 Topics are only shown that are taught at least two schools 
Table III: Comparison of Teaching Methods used on OM "Core Courses" in MBA Programmes

\begin{tabular}{|c|c|c|c|c|c|c|c|}
\hline & School & $\begin{array}{l}\text { Sessions } \\
\text { (Total } \\
\text { Duration) }\end{array}$ & $\begin{array}{l}\text { Number of sessions } \\
\text { using cases (\%tage } \\
\text { of sessions) }\end{array}$ & Videos & $\begin{array}{c}\text { Games / } \\
\text { Simulations }\end{array}$ & Factory Visits & Guest Speakers \\
\hline 1. & Ashridge & $\begin{array}{l}12 \text { sessions } \\
(51 \text { hours })\end{array}$ & $\begin{array}{c}6 \text { sessions } \\
(50 \%)\end{array}$ & Yes & Yes & $\begin{array}{l}\text { Service operation / } \\
\text { factory }\end{array}$ & None \\
\hline 2. & SDA Bocconi & $\begin{array}{c}38 \text { sessions } \\
(76 \text { hours })\end{array}$ & $\begin{array}{c}19 \text { sessions } \\
(50 \%)\end{array}$ & $\begin{array}{l}\text { Yes (inc. video } \\
\text { provided with } \\
\text { Harvard case) }\end{array}$ & $\begin{array}{c}\text { Sampson Game (4 } \\
\text { hours) }\end{array}$ & $\begin{array}{c}2-3 \text { visits: } 6 \text { hours } \\
(8 \%)\end{array}$ & 1 \\
\hline 3. & Cranfield & $\begin{array}{l}25 \text { sessions } \\
(25 \text { hours })\end{array}$ & $\begin{array}{c}19 \text { sessions } \\
(76 \%)\end{array}$ & 2 & $\begin{array}{l}\text { Sampson and JIT } \\
\text { game ( } 2 \text { hours) }\end{array}$ & None & $\begin{array}{c}2 \text { (one } \\
\text { manufacturing, one } \\
\text { service) }\end{array}$ \\
\hline 4. & EAP & $\begin{array}{l}12 \text { sessions } \\
\text { (36 hours) }\end{array}$ & $\begin{array}{c}6 \text { sessions } \\
(50 \%)\end{array}$ & None & $\begin{array}{c}\text { Own JIT game (2 } \\
\text { hours) }\end{array}$ & $\begin{array}{c}\text { 2: each } 41 / 2 \text { hours } \\
(13 \%)\end{array}$ & None \\
\hline 5. & IMD & $\begin{array}{l}17 \text { sessions } \\
(22 \text { hours })\end{array}$ & $\begin{array}{c}15 \text { sessions } \\
(88 \%)\end{array}$ & 2 & $\begin{array}{c}\text { Inventory } \\
\text { management } \\
\text { exercise (1 } 1 / 2 \\
\text { hours) }\end{array}$ & None $^{1}$ & None $^{1}$ \\
\hline 6. & INSEAD & $\begin{array}{l}16 \text { sessions } \\
(24 \text { hours) }\end{array}$ & $\begin{array}{c}11 \text { sessions } \\
(69 \%)\end{array}$ & Yes & No & $\begin{array}{l}\text { Voluntary (outside } \\
\text { the course) }\end{array}$ & None \\
\hline 7. & Lancaster & $\begin{array}{c}9 \text { sessions } \\
(36 \text { hours }) \\
\end{array}$ & $\begin{array}{c}5 \text { sessions } \\
(56 \%)\end{array}$ & None & $\begin{array}{c}2 \text { simulations ( } 31 / 2 \\
\text { hours) }\end{array}$ & Yes & $1-2$ \\
\hline 8. & LBS & $\begin{array}{l}10 \text { sessions } \\
\text { (30 hours) }\end{array}$ & $\begin{array}{l}8 \text { sessions } \\
(73 \%)\end{array}$ & $\begin{array}{l}\text { Several (inc. own } \\
\text { productions) }\end{array}$ & $\begin{array}{c}6 \text { hours of } \\
\text { simulations }\end{array}$ & 3 visits & None $^{2}$ \\
\hline 9. & Groupe ESC Lyon & $\begin{array}{l}12 \text { sessions } \\
\text { (18 hours) }\end{array}$ & $\begin{array}{l}6 \text { sessions } \\
(50 \%)\end{array}$ & 2 videos & $\begin{array}{c}\text { Several short } \\
\text { computer-based } \\
\text { exercises }\end{array}$ & None & During factory visits \\
\hline 10. & Warwick & $\begin{array}{l}10 \text { sessions } \\
(28 \text { hours })\end{array}$ & $\begin{array}{c}8 \text { sessions } \\
(80 \%)\end{array}$ & $\begin{array}{c}1 / 2 \text { hour per week } \\
(15 \%)\end{array}$ & None & $\begin{array}{l}\text { During students free } \\
\text { time. } 12 \text { visits } \\
\text { offered, one is } \\
\text { compulsory }\end{array}$ & None \\
\hline
\end{tabular}

${ }^{1}$ IMD do not use guest speakers or factory visits as they focus heavily on the sharing of participants' operations experiences - see text.

${ }^{2}$ The videos used by LBS include interviews with operations managers discussing issues and prolems. 